УДК 338.2

\title{
ОЦІНЮВАННЯ СТАТИСТИЧНОГО ПОКАЗНИКА ВВП ЯК МІРИ СОЦІАЛЬНОГО ДОБРОБУТУ ТА РЕЗУЛЬТАТИВНОСТI ЕКОНОМІК
}

\section{EVALUATION OF GDP AS A MEASURE OF SOCIAL WELFARE AND THE ECONOMIES' PEFORMANCE}

\author{
Цапко-Піддубна Ольга Іванівна \\ кандидат економічних наук, доцент, \\ Львівський національний університет імені Івана Франка \\ ORCID: https://orcid.org/0000-0002-7233-6019 \\ Tsapko-Piddubna Olga \\ Ivan Franko National University of Lviv
}

\begin{abstract}
У статті розглянуто методологічну обмеженість статистичного показника ВВП та скоригованого показника ВВП на душу населення, яка полягає у неврахуванні сучасних потреб суспільства в зниженні рівня нерівності доходів та багатства, в зменшенні негативного впливу людської діяльності на навколишнє середовище, зростаючих боргових зобов'язань теперішнього та майбутніх покоління та інші. В результаті порівняльного аналізу економік за показниками ВВП на душу населення та за Індексом інклюзивного розвитку (IIP), можна зробити висновок, що використання єдиного показника ВВП на душу населення при аналізі результативності економіки та виміру соціального добробуту є недостатнім. В протилежному випадку, одні країни є переоціненими, інші - недооціненими. Використання альтернативних до ВВП стратегій вимірювання соціального добробуту та результативності економіки, окрім максимізації зростання виробництва, спричинить перехід до виявлення та вирішення складніших суспільних питань сьогодення.

Ключові слова: ВВП, ВВП на душу населення, Індекс інклюзивного розвитку, соціальний добробут, результативність економіки.

В статье рассмотрены методологическую ограниченность статистического показателя ВВП и скорректированного показателя ВВП на душу населения. Эта ограниченность заключается в неучете современных потребностей общества в снижении уровня неравенства доходов и богатства, в уменьшении негативного влияния человеческой деятельности на окружающую среду, растущих долговых обязательств нынешнего поколения и их переноса на будущие поколения и другие. В результате сравнительного анализа экономик по показателям ВВП на душу населения и по Индексу инклюзивного развития (ИИР), можно сделать вывод, что использование единого показателя ВВП на душу населения при анализе результативности экономики и измерения социального благосостояния недостаточно. В противном случае, одни страны являются переоцененными, другие - недооцененными. Использование альтернативных стратегий измерения социального благосостояния и результативности экономики, кроме максимизации роста производства, повлечет переход к выявлению и решению сложных общественных вопросов современности.
\end{abstract}

Ключевые слова: ВВП, ВВП на душу населения, Индекс инклюзивного развития, социальное благополучие, результативность экономики.

The article considers the methodological limitations of GDP and GDP per capita to respond to the current needs of society to reduce income and wealth inequality, the negative impact of human activities on the environment, growing debtness of present and future generations and other. Thus, the main purpose behind the study is to compare counties' economic performance using GDP per capita and the Inclusive Development Index (IID) in order to define whether countries follow the same pattern of development on the basis of different matrics. As a result of the comparative analysis different performance outcomes are observed for economies in terms of GDP per capita and the IDI. Some countries succeeded in making their growth processes more socially inclusive as they have significantly higher scores in IDI world ranking than based on GDP per capita. The other have significantly lower rankings in IDI than in GDP per capita, suggesting that their economic growth has not transformed well into social inclusion. The United States is a good example of limits of GDP per capita as a means of measuring economic activity, social welfare and prosperity. Despite the positive dynamics of GDP per capita, the influence of the other, no less important indicators, 
is strong enough to worsen the overall performance of the economy. Countries with higher GDP per capita rating exploit a materialistic concept of higher production. The use of alternative strategies for measuring social welfare and economic performance, in addition to output growth, will allow to identify and address more complex societal issues. In addition, it is advisable for Ukraine to choose alternative strategies for measuring social welfare and economic performance along with GDP metrics that altogether will better reflect the real trends of national economy development. Besides, development of Norway and Iceland may serve as benchmark for Ukraine.

Keywords: GDP, GDP per capita, Inclusive Development Index, social welfare, economic efficiency.

Постановка проблеми. ВВП - статистичний показник, який протягом багатьох десятиліть був та й сьогодні залишається головним інструментом для опису економічних процесів у національних економіках більшості країн світу. Спершу ВВП було задумано як показник для вимірювання загального випуску товарів та послуг. Проте, сьогодні ВВП, а особливо темпи його зростання, є універсальним показником розвитку, добробуту та геополітичної сили. За матеріалістичної концепції ВВП, вищі темпи виробництва $€$ єдиним імперативом. Та все ж таки все частіше постає питання чи високі та стійкі темпи зростання ВВП чи скоригованого показника ВВП на душу населення сприяють реальному підвищенню якості життя людей, добробуту суспільств та чи здатен цей показник описувати сучасні економічні реалії.

Аналіз останніх досліджень і публікацій. Науковці та політики неоднозначно відносяться до показника ВВП. Одні його ідеалізують, інші - піддають сумніву достатність та ефективність показника ВВП для опису економічних процесів сучасності. Адже, економічні умови і виклики того часу, коли його було розроблено (в часи Великої депресії) кардинально відрізняються від сьогоднішніх.

До прикладу, Ф. Лепеніс вважає, що вихід за межі ВВП та запровадження нового показника - це непростий виклик, адже будь-який альтернативний показник і будь-яка інша стратегія вимірювання, окрім зростання виробництва, вимагатиме від політиків вирішення складніших суспільних та глобальних питань [1]. Насправді, даний показник підтримує політику максимізації виробництва та нівелює проблеми нерівного розподілу доходів та багатства. Економічна політика зводиться до збільшення розмірів пирога і по замовчуванню кожен згодом отримає більший його кусень.

У. Ронер зазначає, що ВВП не $є$ адекватним показником для вимірювання економічного розвитку та соціального добробуту. Увагу звернено на те, що ВВП, як мірило загальної економічної активності себе вичерпав, в умовах, коли зростання корпоративних доходів випе- реджає темпи зростання ВВП в певних країнах. Зокрема, у країнах, де іноземні корпорації володіють значною частиною виробництва та іншими активами, значення показника ВВП буде завищеним. До прикладу, у 2015 ВВП Ірландії зріс на рекордні для країни 26,3 \%. В результаті ОЕСР піддала сумніву можливість ВВП адекватно відображати економічну реальність та ефективно описувати економічну результативність економіки. Як альтернативу було запропоновано використовувати модифіковану версію валового національного доходу. Разом з тим, У. Ронер зазначає, що потрібно зосередитися на усунені недоліків показника ВВП, а не на пошуку абсолютно нових альтернативних показників [2].

Дж. Стігліц - нобелівський лауреат, вбачає конорлікт інтересів у внесені змін у методологію обрахунку ВВП: уряди цілеспрямовано максимізують зростання ВВП, в той час як громадяни намагаються змістити акценти на посилення безпеки, зменшення забруднення довкілля, зниження рівня шумового забруднення, що істотно в довгостроковому періоді матиме негативний вплив на зростання ВВП [3; 4]. Отож, допоки уряди максимізують зростання показника приросту ВВП (в реальності це зростання випуску щоразу більшої кількості товарів та послуг), доти підвищення якості, енергоесрективності та екологічності не буде враховано. Також, на думку вченого, статистичний показник - ВВП на душу населення аж ніяк не відображає реальний добробут громадян та не описує зростаючу нерівність розподілу доходів та багатства [3].

Критикуючи показник ВВП, Р. Констанза та ін. зазначають, що, при підрахунку ВВП не враховано різні види економічної діяльності, які не оплачуються, як от догляд за дітьми, людьми похилого віку та неповносправними. Врахування такої економічної активності (а це, по суті, надання послуг) з однієї сторони, завищило б поточні показники ВВП країн, а 3 іншого, не збільшило існуючого реального економічного добробуту [5].

Також при підрахунку ВВП не враховано вартість усіх вироблених послуг, зокрема, послуг, які надаються інноваційно-технологічними 
компаніями як Google, YouTube, Wikipedia, Facebook, Twitter, Mozilla, Netscape та інших. Ці компанії не виробляють товарів та надають безкоштовні послуги, в результаті, їхню економічну діяльності не враховано у ВВП країни. Тому при виробленні нового, або при доопрацюванні існуючого показника ВВП, необхідно брати до уваги нові види підприємницької діяльності та враховувати їхні особливості [6].

Отож, основна теза науковців, які вбачають необхідність доопрацювання методології обрахунку ВВП або у створені нових альтернативних показників, полягає у тому, що для розуміння економіки як цілісного організму, необхідні адекватні показники. Саме адекватні показники, які відображають реальний стан справ в національних економіках, $€$ основним орієнтиром при реалізації та моніторингу результативності економічних політик. Якщо показник ВВП та скоригований ВВП на душу населення спотворюють реальний стан справ, їхня ефективність застосування підлягає сумніву.

Мета статті. Зважаючи на наукову та практичну актуальність теми, метою даного дослідження $€$ здійснити порівняльний аналіз ефрективності застосування статистичних показників - ВВП на душу населення та Індексу інклюзивного розвитку - для вимірювання соціального добробуту та результативності економіки на прикладі розвинутих країн та країн, що розвиваються, у тім числі України. В результаті проведеного аналізу, виокремити країни для наслідування для України.

Виклад основного матеріалу дослідження. Розуміючи методологічну обмеженість статистичного показника ВВП, а також, враховуючи потреби сучасності суспільств в зниженні рівня нерівності доходів та багатства, в зменшенні негативного впливу виробництва на екологію та перекладання взятих сьогодні фрінансових зобов'язань на майбутні покоління, міжнародні організації та науковці розробляють альтернативні показники, які покликані краще описувати суспільний добробут та прогрес. Серед них переважно індекси, зокрема: Індекс людського розвитку (англ. Human Development Index), Індекс кращого життя (англ. OECD Better Life Index), Індекс сталого розвитку (англ. Sustainable Development Index) та інші. На особливу увагу заслуговує Індекс інклюзивного розвитку (англ. Inclusive Development Index), розроблений Світовим економічним фрорумом як альтернатива показнику ВВП, який $є$ кількісним виміром процесів, що характеризують інклюзивність економічного зростання країни.
Цей індекс $є$ агрегованим показником, який сорормовано на основі трьох груп показників. Зокрема, перша група показників описує економічне зростання та розвиток країни (ВВП на душу населення, продуктивність праці, тривалість життя та зайнятість), друга група - інклюзивність та нерівність (GINI-розподіл чистого доходу, GINI-розподіл багатства, рівень бідності та середній дохід), а третя група - рівність можливостей між поколіннями та сталість (скориговані чисті заощадження, викиди $\mathrm{CO}_{2} / \mathrm{BBП}$, державний борг та коефріцієнт демограсрічного навантаження). Завершальна група показників $є$ важливою, оскільки розрахована для моніторингу не лише існуючих проблем економічного розвитку та нерівності у суспільстві, а й для виявлення можливих негативних тенденцій у майбутньому та для запобігання зростанню нерівності між поколіннями [7].

Отож, проаналізуємо та порівняємо результативність вибраних національних економік (країн-лідерів за інклюзивністю серед розвинутих країн та країн, що розвиваються), зокрема, їхні позиції у рейтингах за ВВП на душу населення та за IIP.

Найбільш інклюзивними країнами 2018 р., відповідно до значень IIP, є: Норвегія $(6,08)$, Ісландія $(6,07)$, Люксембург $(6,07)$, Швейцарія $(6,05)$, Данія $(5,81)$, Швеція $(5,76)$, Нідерланди $(5,61)$, Ірландія $(5,44)$, Австралія $(5,36)$, та Австрія $(5,35)$, що відображено на рис. 1.

До рейтингу десятки країн з найвищим ВВП на душу населення у 2018 р. входять (по мірі спадання): Люксембург, Норвегія, Швейцарія, Ірландія, Данія, Швеція, Австралія, Сінгапур, США та Нідерланди.

Для більшості розвинутих країн позиції у рейтингах за IIP та ВВП на душу населення або збігаються, або відмінності є незначними. Проте для певних країн ця різниця $є$ значною. До прикладу, Ісландія у рейтингу IIP займає 2-гу позицію у світі, тоді як за ВВП на душу населення - 12. Такі відмінності відображують позитивну тенденцію розвитку країни, оскільки кращі позиції за IIP засвідчують іï̈ соціально збалансований економічний розвиток, який сприятиме стійкому зростанню у майбутньому.

За протилежної ситуації, коли країна займає значно вищі позиції у рейтингу за ВВП на душу населення, ніж за IIP, існує потенціал та необхідність до генерування більш інклюзивного економічного зростання. Ця рекомендація буде актуальною для США та Японії - країн, які, відповідно, займають 9-ту та 14-ту позицію у світі за ВВП на душу населення та лише 23-тю та 24-ту - за IIP [8]. 


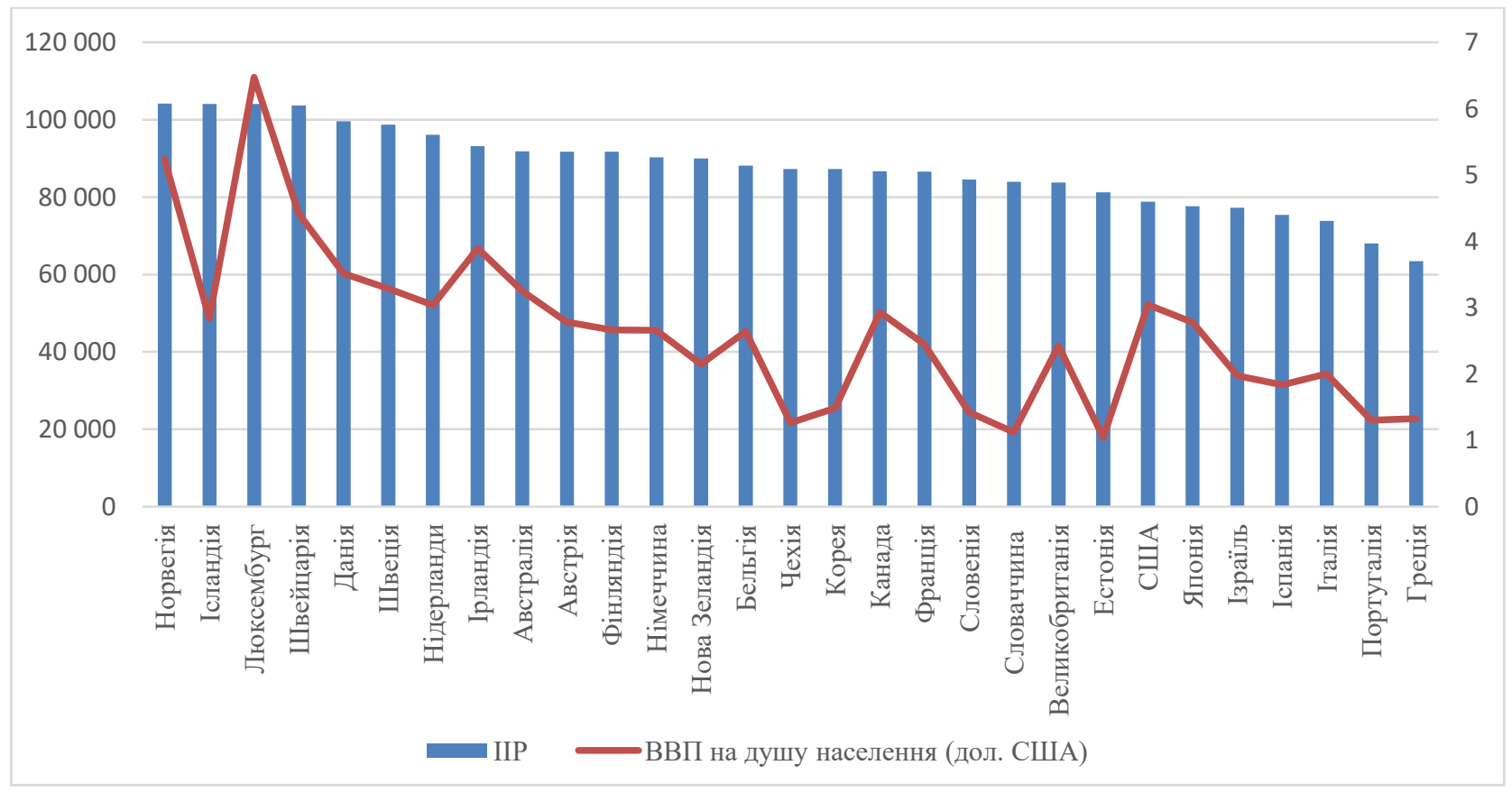

Рис. 1. IIP та ВВП на душу населення для розвинутих країн, 2018 р. [8]

Серед країн, що розвиваються, лідерами за інклюзивністю зростання є: Литва $(4,86)$, Угорщина $(4,74)$, Азербайджан $(4,69)$, Латвія $(4,67)$, Польща $(4,61)$, Панама $(4,54)$, Хорватія $(4,48)$, Уругвай $(4,46)$, Чилі $(4,44)$ та Румунія $(4,43)[8]$. Водночас серед країн, що розвиваються, $€$ ті, котрі демонструють кращі результати щодо акумулювання саме інклюзивного зростання, ніж розвинуті країни. Загалом для 43-х країн, що розвиваються, значення IIP перевищує 3,70 - найнижчий показник серед розвинутих країн, який належить Греції.

Лідерами за ВВП на душу населення (по мірі спадання) серед країн, що розвиваються $€$ : Литва, Польща, Чилі, Угорщина, Латвія, Хорватія, Туреччина, Уругвай, Росія та Малайзія.

Великі розриви між рейтингами за двома показниками спостерігаємо для Азербайджану (26-те місце за ВВП на душу населення та 3 місце за IIP) та для Росії (9-те місце за ВВП на душу населення та 19-те - за ІІР). Ситуація Азербайджану свідчить про позитивну тенденцію розвитку країни в аспекті інклюзивності економічного зростання, тоді як Росії - негативну.

Щодо України, то вона посіла 43-тє місце (із 77-ми країн світу, що розвиваються) за ВВП на душу населення та 49-те - за IIP.

Отож, беручи до уваги вищенаведену статистику та різну результативність економік за двома згаданими показниками, можна припустити, що дійсно показник ВВП на душу населення досить поверхнево описує добробут населення. Цей показник не враховує низку чинників, які мають не менш важливий вплив на довготривалий стійкий розвиток країни та добробут ії теперішніх та майбутніх громадян.

Щоб, детальніше зрозуміти значну розбіжність між рейтингами Ісландії (12-та позиція у рейтингу ВВП на душу населення та 2-га країна у світі за IIP) та США (відповідно, 9-те та 23-тє місце) та виокремити країни для наслідування для України (у якої показник IIP у 1,8 раза нижчий, ніж у Норвегії - країни-лідера за IIP та в 1,4 раза - ніж у середньому для Польщі та Угорщини - колишніх постсоціалістичних країнах, які, як і Україна, здійснювали перехід до ринкових умов господарювання), проаналізуємо детальніше результативність економік Норвегії, Ісландії, США, Польщі, Угорщини та України на основі показників, які фрормують IIP (рис. 2).

Отож, висока інклюзивність економічного зростання Ісландії обумовлена позитивними значеннями усіх показників (див. рис. 2). Окремо варто наголосити на значних досягненнях цієї країни у рівності розподілу доходів та володіння економічними активами, адже показники GINI-розподіл чистого доходу $(24,4)$ та GINIрозподілу багатства $(46,7) \in$ доволі низькими ${ }^{1}$.

\footnotetext{
${ }^{1}$ Показники можуть набувати значень від 0 до 100, де 0 свідчить про абсолютну рівність у розподілі чистого доходу/ багатства, а 100 - нерівність.
} 


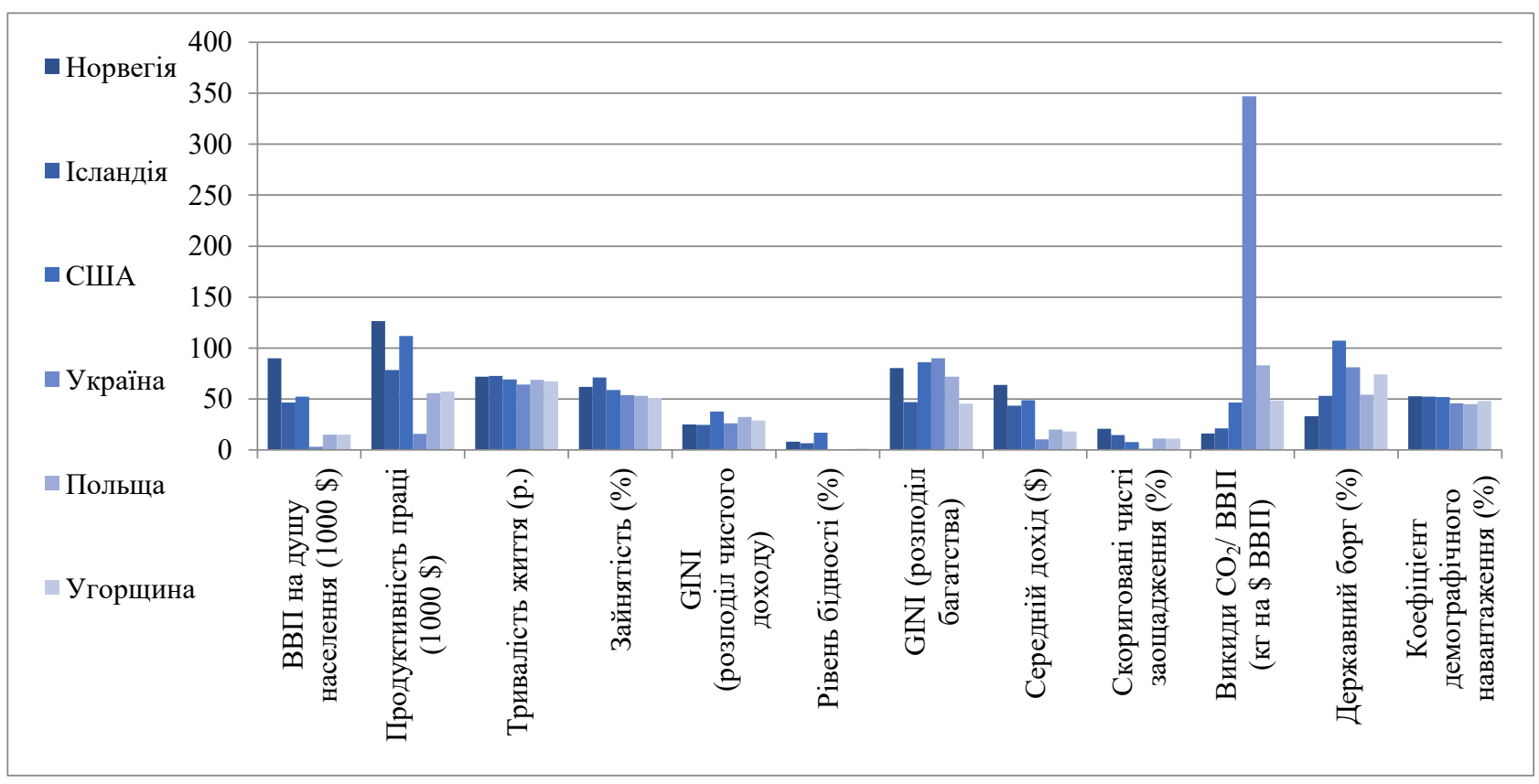

Рис. 2. Показники IIP 2018 р. [8]

У США ситуація протилежна. Обидва показники, які описують нерівність доходу та багатства набувають значно вищих значень (37,8 та 85,9, відповідно) й описують ситуацію зростаючої економічної нерівності у цій країні. Окрім цього, відносно низька інклюзивність економічного зростання США (23-тє місце у світі), незважаючи на високі показники ВВП на душу населення (9-те місце у світі) та продуктивності праці (4-те місце у світі), зумовлена високим рівнем бідності ${ }^{2}$, низьким рівнем заощаджень ${ }^{3}$ та значним державним боргом. США $€$ прикладом недостатності показника ВВП на душу населення для вимірювання економічної успішності країни. Незважаючи на позитивну динаміку ВВП на душу населення, інші, не менш важливі показники, занижують загальну результативність економіки.
В Угорщині та Польщі спостерігаємо позитивну динамікуу групі показників інклюзивності та у групі рівності можливостей між поколіннями та сталості. 3 метою підвищення загальної результативності в аспекті інклюзивного зростання, варто розвивати продуктивне виробництво товарів та послуг з паралельною позитивною динамікою двох інших агрегованих показників.

Для України спостерігаємо низьку результативність усіх трьох груп показників IIP, що відображено у таблиці 1.

Прикладом для наслідування та змін парадигми економічного розвитку України можуть слугувати країни, які є лідерами за показником IIP - Норвегія та Ісландія, оскільки позитивна зростаюча динаміка цього показника свідчить не лише про зростання приросту ВВП

Інклюзивність економічного зростання за групами показників IIP 2018 р.

Таблиця 1

\begin{tabular}{|c|c|c|c|c|c|}
\hline & \multirow{2}{*}{$\begin{array}{c}\text { Економічне } \\
\text { зростання } \\
\text { та розвиток }\end{array}$} & \multirow[b]{2}{*}{ Інклюзивність } & \multirow{2}{*}{$\begin{array}{c}\text { Рівність } \\
\text { можливостей } \\
\text { між поколіннями } \\
\text { та сталість }\end{array}$} & \multicolumn{2}{|c|}{ IIP } \\
\hline & & & & 2017 p. & $2018 \mathrm{p}$. \\
\hline Норвегія & 6,36 & 5,67 & 6,03 & 6,02 & 6,08 \\
\hline Ісландія & 5,51 & 5,77 & 5,17 & 5,48 & 6,07 \\
\hline США & 5,35 & 3,53 & 4,44 & 4,44 & 4,60 \\
\hline Україна & 2,99 & 4,28 & 3,74 & 3,67 & 3,42 \\
\hline Польща & 3,67 & 4,69 & 5,35 & 4,57 & 4,61 \\
\hline Угорщина & 3,48 & 5,18 & 5,06 & 4,57 & 4,74 \\
\hline
\end{tabular}

Джерело: складено автором за [8]

2 До прикладу, у Норвегії та Ісландії рівень бідності, відповідно, нижчий у 2 рази та 2,5 раза.

${ }^{3}$ щодо скоригованих чистих заощадження, то у Норвегії та Ісландії вони, відповідно, вищі у 3 та 2 рази, ніж у США. 
на душу населення, а й враховує позитивну динаміку інших показників, які сукупно відображають реальні тенденції розвитку країни. Досвід Литви та Угорщини теж буде корисним, адже цим країнам вдалось змістити акценти з високих темпів зростання ВВП на користь інклюзивного розвитку суспільства.

Висновки. Показника ВВП та скоригованого показника ВВП на душу населення $€$ недостатньо для ефективного виміру людського добробуту та економічного прогресу в країні. Адже, збільшення ВВП та ВВП на душу населення не означає підвищення рівня життя населення. Методологічна обмеженість статистичного показника ВВП полягає у неврахуванні сучасних потреб суспільств в зниженні рівня нерівності доходів та багатства, в зменшенні негативного впливу людської діяльності на навколишнє середовище, в зменшенні боргового тягаря на майбутні покоління та інше. Відмова від ВВП та перехід на альтернативні показники змусить урядовців зміщувати акцент уваги з досягнення високих темпів економічного зростання до вирішення складніших суспільних та глобальних питань.
На основі порівняльного аналізу результативності економік за показниками ВВП на душу населення та за IIP, можна зробити висновок, що недостатнім $€$ використання єдиного показника ВВП на душу населення при аналізі результативності економіки та виміру соціального добробуту. В такому випадку, Ісландія - друга найбільш інклюзивна економіка, була б недооцінена, а США - переоцінені. Ісландія, країна, яка гармонійно розвивається в різних економічних аспектах. США - країна, яка максимізує нарощування виробничого потенціалу та підвищує продуктивність національної економіки, проте, не вирішує проблем нерівномірного розподілу доходів та багатства, високого рівня бідності, низького рівня заощаджень та значного державного боргу.

Прикладом для наслідування та змін парадигми економічного розвитку України можуть слугувати країни, які є лідерами за показником IIP - Норвегія та Ісландія, оскільки позитивна зростаюча динаміка цього показника свідчить не лише про зростання приросту ВВП на душу населення, а й враховує позитивну динаміку інших показників, які сукупно відображають реальні тенденції розвитку країни.

\section{СПИСОК ВИКОРИСТАНИХ ДЖЕРЕЛ:}

1. Lepenies P. Why GDP? / Project Syndicate. 2016. Available at: https://www.project-syndicate.org/bigpicture/ the-trouble-with-gdp

2. Rohner U. GDP Should Be Corrected, Not Replaced / Project Syndicate. 2018. Available at: https://www.project-syndicate.org/bigpicture/the-trouble-with-gdp

3. Stiglitz J. GDP Is the Wrong Tool for Measuring What Matters / Scientifiv American. 2020. Available at: https://www.scientificamerican.com/article/gdp-is-the-wrong-tool-for-measuring-what-matters/

4. Stiglitz J. E. Rewriting the Rules of the American Economy. 2016. Available at: https://community-wealth.org/ sites/clone.community-wealth.org/files/downloads/report-stiglitz.pdf

5. Costanza R., Maureen H., Posner S., Talberth J. Beyond GDP: The Need for New Measures of Progress I The PARDEE PAPERS. No. 4. 2009. Available at: https://www.bu.edu/pardee/files/documents/PP-004-GDP.pdf

6. Van den Bergh J., Antal M. Evaluating Alternatives to GDP as Measures of Social Welfare/Progress/ WWWforEurope Working Paper, No. 56. 2014. Available at: https://www.econstor.eu/bitstream/10419/125713/1/ WWWforEurope_WPS_no056_MS211.pdf

7. World Economic Forum. The Inclusive Growth and Development Report 2017. Available at: https://www.weforum.org/reports/the-inclusive-growth-and-development-report-2017

8. World Economic Forum. The Inclusive Development Index 2018 Summary and Data Highlights / World Economic Forum. 2018. Available at: http://www3.weforum.org/docs/WEF_Forum_IncGrwth_2018.pdf

\section{REFERENCES:}

1. Lepenies P. (2016) Why GDP? / Project Syndicate. Available at: https://www.project-syndicate.org/bigpicture/ the-trouble-with-gdp

2. Rohner U. (2018) GDP Should Be Corrected, Not Replaced / Project Syndicate. Available at: https://www.project-syndicate.org/bigpicture/the-trouble-with-gdp

3. Stiglitz J. (2020) GDP Is the Wrong Tool for Measuring What Matters / Scientifiv American. Available at: https://www.scientificamerican.com/article/gdp-is-the-wrong-tool-for-measuring-what-matters/

4. Stiglitz J. E. (2016) Rewriting the Rules of the American Economy. Available at: https://community-wealth.org/ sites/clone.community-wealth.org/files/downloads/report-stiglitz.pdf 
5. Costanza R., Maureen H., Posner S., Talberth J. (2009) Beyond GDP: The Need for New Measures of Progress / The PARDEE PAPERS, no. 4. Available at: https://www.bu.edu/pardee/files/documents/PP-004-GDP.pdf 6. Van den Bergh J., Antal M. (2014) Evaluating Alternatives to GDP as Measures of Social Welfare / Progress / WWWforEurope Working Paper, no. 56. Available at: https://www.econstor.eu/bitstream/10419/ 125713/1/WWWforEurope_WPS_no056_MS211.pdf

7. World Economic Forum (2017) The Inclusive Growth and Development Report. Available at: https://www.weforum.org/reports/the-inclusive-growth-and-development-report-2017

8. World Economic Forum (2018) The Inclusive Development Index 2018 Summary and Data Highlights / World Economic Forum. Available at: http://www3.weforum.org/docs/WEF_Forum_IncGrwth_2018.pdf 